\title{
SIMULASI BEBAN JALAN DAN TRAKSI RODA PADA PEMILIHAN ROLLING CHASSIS 4WD UNTUK KENDARAAN WATER CANNON
}

\section{ROAD LOAD AND WHEEL TRACTION SIMULATION OF 4WD ROLLING CHASSIS SELECTION FOR WATER CANNON VEHICLE}

\author{
Prasetyaning Diah Rizky Lestaria ${ }^{\text {, Agus Sartomo }}{ }^{\mathrm{a}}$, Taufik Yuwono ${ }^{\mathrm{a}}$ \\ a Balai Teknologi Termodinamika, Motor dan Propulsi - BPPT, Gedung 230, Kawasan Puspiptek \\ Serpong, Tangerang Selatan, 15314. \\ e-mail : diah.rizky@bppt.go.id, agus.sartomo@bppt.go.id, taufik.yuwono@bppt.go.id
}

\begin{abstract}
Abstrak
Tingkat kandungan dalam negeri (TKDN) pada kendaraan taktis Water Cannon (WCV) milik Polri yang rendah mendorong adanya kajian yang mengarah pada peningkatan nilai TKDN. Salah satu penguasaan teknologi dalam pengembangan kendaraan taktis yaitu dengan memilih beberapa komponen tertentu dari kendaraan yang mempunyai daya ungkit tinggi dalam meningkatkan TKDN hingga mencapai $25 \%$ atau lebih. Dalam kajian ini komponen yang dipilih yaitu berupa rolling chassis kendaraan. Sesuai dengan spesifikasi kendaraan WCV Tactica milik Polri maka pada kajian ini dipilih WCV 4WD dengan tujuan kendaraan dapat digunakan di medan jalan tanah dan lincah dalam bermanuver. Rolling chassis akan dipilih berdasarkan hasil simulasi performanya berdasarkan beban jalan kendaraan dan traksi roda yang dihasilkan. Simulasi perhitungan dilakukan dengan menggunakan 3 macam merek rolling chassis 4WD yaitu A, B dan C yang tersedia di pasaran lokal Indonesia. Tinjauan utama dalam membandingkan 3 merek rolling chassis ini adalah kemampuan tanjaknya serta kecepatan yang dapat dicapai pada kemampuan tanjak tersebut. Dari hasil kajian disimpulkan bahwa secara keseluruhan desain kendaraan WCV dengan menggunakan rolling chassis merek $\mathrm{B}$ lebih layak digunakan. Dengan rolling chassis merek $\mathrm{B}$, kendaraan WCV dapat melalui tanjakan hingga $30^{\circ}$ dengan kecepatan maksimal $9 \mathrm{~km} / \mathrm{jam}$. Simulasi beban jalan kendaraan dan traksi roda ini dapat digunakan sebagai salah satu metode acuan pemilihan rolling chassis untuk kendaraan WCV.
\end{abstract}

Kata kunci : Traksi, Beban Jalan Kendaraan, Rolling Chassis, Water Cannon Vehicle

\begin{abstract}
The low level of domestic content (TKDN) in the Water Cannon Vehicle (WCV) owned by Indonesian Police (Polri) encourages a study that leads to an increase in the value of TKDN. One of the mastery of technology in the development of tactical vehicles is by selecting some particular components of vehicle that have high leverage in increasing TKDN up to $25 \%$ or more. In this study, the selected component is in the form of vehicle rolling chassis. In accordance with the specification of WCV Tactica vehicle owned by Polri, 4WD WCV is selected in this study, considering this vehicle can be used on the ground and nimble in maneuvering. Final rolling chassis will be selected based on its performance simulation result based on the vehicle's road loads and wheel traction. Simulation is done by using 3 types of $4 W D$ rolling chassis brand i.e. brand $A, B$ and $C$ which are available in Indonesia local market. The review points in comparing these 3 brands of rolling chassis are its climbing capability and the speed that can be achieved in that climbing
\end{abstract}


capability. From the results of the study concluded that the overall design of WCV using rolling chassis brand $B$ is more feasible to use. By using rolling chassis brand $B, W C V$ can climb up to $30^{\circ}$ with a maximum speed of $9 \mathrm{~km} / \mathrm{h}$. The simulation of road loads and wheel traction can be used as one of the reference methods for selecting rolling chassis for WCV.

Keywords: Traction, Road Load, Rolling Chassis, Water Cannon Vehicle

Diterima (received ) : 17 Januari 2019 , Direvisi (revised ) : 28 Februari 2019

Disetujui (accepted) : 08 Maret 2019

\section{PENDAHULUAN}

Program Pembangunan di bidang Pertahanan dan Keamanan Nasional merupakan salah satu prioritas Pemerintah dalam menjamin keamanan dan kedaulatan negara. Dalam pembangunan kekuatan Alat dan Peralatan Pertahanan dan Keamanan (Alpalhankam, termasuk Alutsista-TNI dan Almatsus-Polri), salah satu strategi untuk memenuhinya adalah dengan meningkatkan peran industri pertahanan dan keamanan dalam negeri. Oleh karena itu, pemberdayaan industri pertahanan dan keamanan dalam negeri terus perlu diupayakan untuk mencapai kemandirian pemenuhan Alutsista-TNI dan AlmatsusPolri'1).

Kendaraan taktis kepolisian adalah kendaraan yang digunakan untuk mendukung kelancaran dan keamanan personil kepolisian dalam menjalankan tugas dalam menjaga keamanan dan ketertiban masyarakat. Salah satunya adalah kendaraan Water Cannon (WCV). WCV merupakan perangkat/ kendaraan yang dapat menembakkan aliran air dengan kecepatan sangat tinggi. Biasanya air yang ditembakkan dalam volume besar dan bahkan dengan jarak lebih dari puluhan meter dengan tujuan untuk mengendalikan massa. Dengan tujuan tersebut, maka kendaraan taktis WCV haruslah memiliki kemampuan yang dibutuhkan dalam pengoperasiannya di lapangan.

Saat ini kendaraan taktis WCV milik Polri mempunyai tingkat kandungan dalam negeri (TKDN) sebesar $0 \%$, karena seluruhnya masih impor dari luar negeri, salah satunya dari Korea ${ }^{2}$. Sedangkan kebutuhan Polri akan kendaraan taktis WCV ini sebanyak 388 unit hingga tahun 20193). Untuk itu diperlukan suatu kajian yang mengarah pada peningkatan nilai TKDN khususnya kendaraan taktis WCV. Penguasaan teknologi dalam pengembangan kendaraan taktis yaitu dengan memilih beberapa komponen dari kendaraan tertentu yang mempunyai daya ungkit tinggi dalam meningkatkan TKDN hingga mencapai 25\% atau lebih. Dalam kajian ini komponen yang diambil yaitu berupa rolling chassis kendaraan.

Kajian ini merupakan bagian dari program BPPT dalam bidang teknologi Rancang Bangun Kendaraan WCV. Hasil kegiatan ini akan digunakan sebagai acuan atau basic design untuk rancang bangun produk kendaraan taktis WCV untuk kebutuhan Polri khususnya untuk rolling chassis.

\section{Data Spesifikasi Kendaraan Taktis WCV Milik Polri}

Data spesifikasi kendaraan taktis WCV milik Polri diperoleh melalui survei lapangan dengan mengunjungi Polda Metro Jaya, Mako Brimob dan Polda Jabar. Dari survei ini diperoleh bahwa Polri telah memiliki beberapa tipe dan merek kendaraan WCV seperti terangkum dalam Tabel 1.

Tabel 1.

Spesifikasi WCV yang dimiliki Polri

\begin{tabular}{|c|c|c|c|}
\hline $\begin{array}{l}\text { Item } \\
\mathrm{P} \times \mathrm{L} \times \mathrm{T} \\
(\mathrm{mm})\end{array}$ & $\begin{array}{c}\text { Tactica } \\
5020 \times 204 \\
5 \\
\times 2320\end{array}$ & $\begin{array}{c}\text { Daeji } \\
8155 \times 249 \\
0 \\
\times 2915\end{array}$ & $\begin{array}{c}\text { Daewoo } \\
6050 \times 244 \\
5 \\
\times 3675\end{array}$ \\
\hline $\begin{array}{c}\text { Kapasitas } \\
\text { tangki air } \\
(\mathrm{Lt})\end{array}$ & 4000 & 6500 & 6500 \\
\hline $\begin{array}{l}\text { Wheel } \\
\text { Drive }\end{array}$ & $4 \times 4$ & $4 \times 2$ & $4 \times 2$ \\
\hline $\begin{array}{l}\text { Jumlah } \\
\text { roda }\end{array}$ & 4 & 6 & 6 \\
\hline Mesin & $\begin{array}{c}\text { Perkins } \\
\text { Phaser } \\
180 \mathrm{Ti}\end{array}$ & $\begin{array}{c}\text { Doosan } \\
\text { DE12TIS }\end{array}$ & $\begin{array}{l}\text { Doosan } \\
\text { DE08TIS }\end{array}$ \\
\hline $\begin{array}{c}\text { Daya } \\
\text { Maks. } \\
\text { (kW/RPM) }\end{array}$ & $\begin{array}{c}134 \\
\mathrm{~kW} / 2600\end{array}$ & $\begin{array}{c}265 \\
\mathrm{~kW} / 2100\end{array}$ & $\begin{array}{c}176 \\
\mathrm{~kW} / 2300\end{array}$ \\
\hline $\begin{array}{c}\text { Torsi } \\
\text { Maks. } \\
\text { (N.m/RPM) }\end{array}$ & $\begin{array}{c}618 / 1400- \\
1600\end{array}$ & $1421 / 1260$ & $882 / 1200$ \\
\hline Konfiguras & $\begin{array}{l}\text { Kabin- } \\
\text { tangki- } \\
\text { pompa }\end{array}$ & $\begin{array}{l}\text { Kabin - } \\
\text { tangki - } \\
\text { pompa }\end{array}$ & $\begin{array}{l}\text { Kabin- } \\
\text { pompa- } \\
\text { tangki }\end{array}$ \\
\hline
\end{tabular}

Sumber Data : Hasil Survei Lapangan 


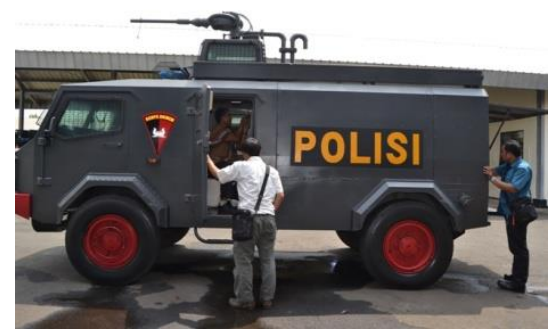

Gambar 1.

Kendaraan Tactica Water Cannon Milik BRIMOB

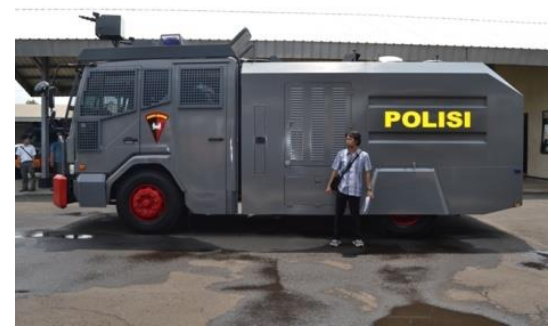

Gambar 2.

Kendaraan Daeji Water Cannon Milik BRIMOB

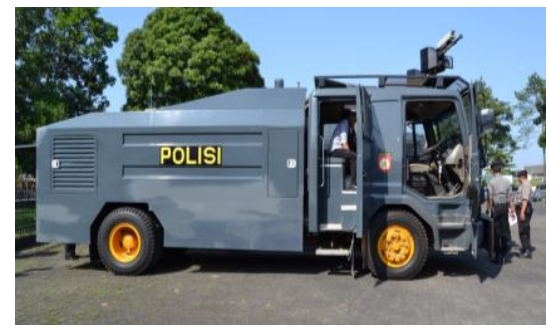

Gambar 3.

Kendaraan Daewoo Water Cannon Milik POLDA JAWA BARAT

\section{METODOLOGI}

Dalam penentuan rolling chassis yang perlu dilakukan adalah penyusunan filosofi rancang bangun kendaraan taktis WCV khususnya pada sistem penggeraknya. Berikut adalah metodologi yang digunakan pada kajian ini.

\section{Eksplorasi Kandidat Rolling Chassis 4WD di pasaran Indonesia}

WCV 4WD merupakan kendaraan taktis yang didesain untuk dapat digunakan di medan jalan tanah dan lincah bermanuver di kondisi jalan yang sempit. Oleh karena itu, sesuai dengan spesifikasi kendaraan WCV Tactica milik Polri maka pada kajian ini dipilih WCV 4WD dengan tujuan agar kendaraan dapat digunakan di medan jalan tanah dan juga lincah dalam bermanuver. Untuk dapat memenuhi kebutuhan tersebut maka dilakukan eksplorasi kandidat rolling chassis 4WD yang tersedia di pasaran Indonesia. Dari rolling chassis 4WD yang tersedia di pasaran Indonesia, dipilih 3 kandidat rolling chassis yaitu merek A, B dan C dengan spesifikasi pada Tabel 2.

Tabel 2.

Perbandingan Spesifikasi Rolling Chassis

\begin{tabular}{|c|c|c|c|}
\hline $\begin{array}{l}\text { Item } \\
P \times L \times T \\
(\mathrm{~mm})\end{array}$ & $\begin{array}{c}\text { Merek A } \\
5905 \times 1920 \\
\times 2120\end{array}$ & $\begin{array}{c}\text { Merek B } \\
5985 \times 2040 \\
\times 2455\end{array}$ & $\begin{array}{c}\text { Merek C } \\
6026 \times 1884 \\
\times 2362\end{array}$ \\
\hline $\begin{array}{l}\text { Wheelbase } \\
(\mathrm{mm})\end{array}$ & 3360 & 3365 & 3380 \\
\hline $\begin{array}{l}\text { Berat } \\
\text { kosong } \\
\text { (kg) }\end{array}$ & 2730 & 2910 & 2875 \\
\hline GVW (kg) & 8250 & 6000 & 7500 \\
\hline $\begin{array}{l}\text { Nomor seri } \\
\text { mesin }\end{array}$ & 4HG1-T & 4HK1-TCN & W04D-TR \\
\hline $\begin{array}{c}\text { Stroke } \\
\text { volume (Lt) }\end{array}$ & 4,57 & 5,193 & 4,009 \\
\hline $\begin{array}{l}\text { Daya Maks. } \\
\text { (PS/RPM) }\end{array}$ & $91 @ 2900$ & $110 @ 2600$ & 95@2700 \\
\hline $\begin{array}{l}\text { Torsi Maks. } \\
\text { (kg.m/RPM) }\end{array}$ & $\begin{array}{c}343 @ 1200 \\
-2200\end{array}$ & $\begin{array}{c}401 @ 1500 \\
-2600\end{array}$ & 372@1800 \\
\hline $\begin{array}{l}\text { Nomor seri } \\
\text { transmisi } \\
\text { Gear ratio }\end{array}$ & MYY5T & MYY5T & M550 \\
\hline 1 & 5,315 & 5,315 & 4,981 \\
\hline 2 & 3,053 & 3,053 & 2,911 \\
\hline 3 & 1,655 & 1,655 & 1,556 \\
\hline 4 & 1 & 1 & 1 \\
\hline 5 & 0,721 & 0,721 & 0,738 \\
\hline Rev & 5,068 & 5,068 & 4,625 \\
\hline $\begin{array}{c}\text { Final gear } \\
\text { ratio } \\
\text { Transfer } \\
\text { case }\end{array}$ & 6,5 & 5,125 & 5,833 \\
\hline $\operatorname{High}(4 \times 2)$ & 1,1 & 1 & 1 \\
\hline $\operatorname{Low}(4 \times 4)$ & 2,2 & 1,842 & 2,2 \\
\hline Ukuran ban & $\begin{array}{l}\text { 7.50-16- } \\
\text { 14PR }\end{array}$ & $\begin{array}{c}\text { 7.50-16R- } \\
10 \mathrm{~L}\end{array}$ & $\begin{array}{c}\text { 205/70R } 17, \\
5\end{array}$ \\
\hline $\begin{array}{l}\text { Kapasitas } \\
\text { tangki (Lt) }\end{array}$ & 100 & 100 & 100 \\
\hline $\begin{array}{l}\text { Radius } \\
\operatorname{putar}(\mathrm{m})\end{array}$ & 6,9 & 7,1 & 6,7 \\
\hline $\begin{array}{c}\text { Daya } \\
\operatorname{tanjakan} \\
(\tan \theta \\
\text { atau \%) }\end{array}$ & 33 & 30 & 56 \\
\hline
\end{tabular}

\section{Klasifikasi dan Perhitungan Berbagai Macam Beban Jalan pada WCV}

Dalam penyusunan rancang bangun kendaraan taktis WCV dalam hal sistem penggerak (rolling chassis) maka perlu dilakukan klasifikasi terkait berbagai jenis beban jalan pada kendaraan. Pada kendaraan yang akan bergerak, daya mesin digunakan untuk mengatasi running 
resistence (beban jalan) yang dialami kendaraan. Dari perhitungan beban jalan ini, dapat diketahui kemampuan mesin pada WCV untuk menjadikannya bergerak.

Jenis-jenis beban jalan yang dialami pada kendaraan WCV diilustrasikan dalam gambar berikut.

\section{Running resistance}

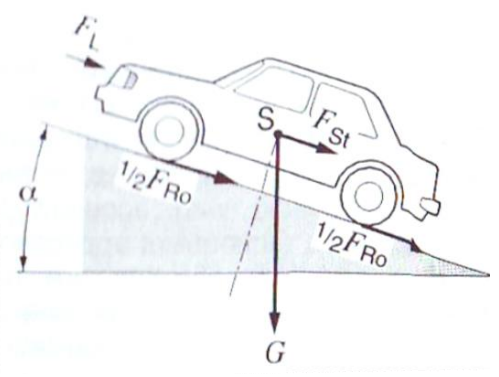

Gambar 4.

Beban Jalan pada Kendaraan

Keterangan:

G : Berat kendaraan

\section{- $\quad$ Beban Rolling $\left(F_{R o}\right)$}

Beban rolling memberikan gaya tahanan pada kendaraan untuk memperlambat gerak kendaraan. Gaya rolling ini merupakan penjumlahan dari komponen-komponen kendaraan yang berotasi. Secara umum, beban rolling ini dihitung dengan persamaan:

$$
F_{R 0}=f * m * g
$$

Keterangan:

$\begin{array}{ll}F_{R O} & : \text { Beban rolling }(\mathrm{N}) \\ F & : \text { Koefisien beban rolling (nilai } \\ & \text { besaran ini ditunjukkan Tabel 3.) } \\ m & : \text { Massa kendaraan }(\mathrm{kg}) \\ g & : \text { Konstanta gravitasi }\left(\mathrm{m} / \mathrm{s}^{2}\right)\end{array}$

Tabel 3.

Koefisien Beban Jalan

\begin{tabular}{cc}
\hline $\begin{array}{c}\text { Permukaan } \\
\text { Jalan }\end{array}$ & $\begin{array}{c}\text { Koefisien } \\
\text { beban rolling }\end{array}$ \\
\hline Jalan paving & 0,015 \\
besar & 0,015 \\
Jalan paving & \\
kecil & 0,013 \\
Beton, aspal & 0,025 \\
Jalan batu & 0,02 \\
Makadam & 0,025 \\
Jalan tanah & $0,1-0,35$ \\
Jalan berumput & \\
\hline Sumber Data : Mashadi dan Crolla $(2012)^{4}$
\end{tabular}

Nilai koefisien $f$ adalah nilai yang ditentukan banyak parameter. Nilai empiris dari koefisien beban jalan pada kondisi jalan yang berbeda-beda ditunjukkan pada Tabel 3. Pada kasus ini dipilih jalan berupa jalan tanah dengan $f=0,025$.

\section{- Beban Aerodinamis $\left(F_{L}\right)$}

Beban aerodinamis pada kendaraan timbul karena adanya gaya yang bekerja dari udara sekitar kendaraan yang bergerak. Beban aerodinamis ini bekerja pada kendaraan dan menyebabkan drag, lift (atau download), gaya lateral, momen dalam bentuk rolling, pitching, dan yawing, serta dapat menimbulkan noise.

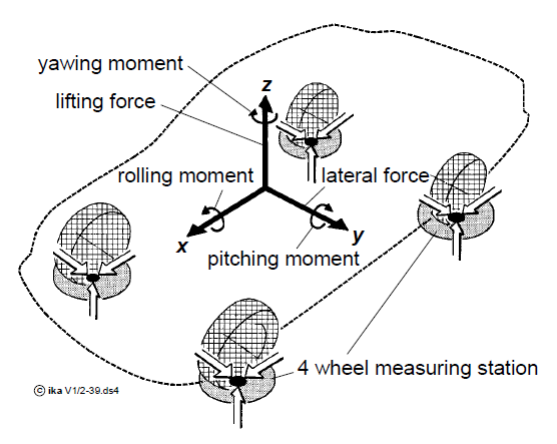

Gambar 5.

Gaya dan momen aerodinamis yang bekerja pada kendaraan

Dalam bahasan ini, karena elemen utama yang bekerja adalah searah dengan arah gerak kendaraan, maka yang akan dihitung dalam bahasan disini adalah gaya longitudinal saja. Beban aerodinamis karena drag dihitung dengan persamaan:

$$
F_{L}=0.5 * \rho * c_{D} * A *\left(\frac{v}{3.6}\right)^{2}
$$

Keterangan:

$$
\begin{array}{ll}
F_{L} & : \text { Beban aerodinamis }(\mathrm{N}) \\
\rho & : \text { Densitas udara }\left(\mathrm{kg} / \mathrm{m}^{3}\right) \\
C_{D} & : \text { Koefisien tahanan udara } \\
A & : \text { Luasan frontal kendaraan }\left(\mathrm{m}^{2}\right) \\
V & : \text { Kecepatan kendaraan }(\mathrm{km} / \mathrm{jam})
\end{array}
$$

Tabel 4. menunjukkan nilai $C_{D}$ untuk persamaan di atas, pada berbagai bentuk kendaraan. Pada kasus ini diasumsikan nilai $C_{D}$ yaitu 0,7 . 


\begin{tabular}{cc}
\hline \multicolumn{2}{c}{ Tabel 4. } \\
\multicolumn{2}{c}{ Referensi Koefisien Tahanan Udara $C_{D}$} \\
\hline Vehicle & $\mathbf{C}_{\mathbf{D}}$ \\
\hline Motorcycle with rider & $0,5-0,7$ \\
Open convertible & $0,5-0,7$ \\
Limousine & $0,22-0,4$ \\
Coach & $0,4-0,8$ \\
Truck without trailer & $0,45-0,8$ \\
Truck with trailer & $0,55-1,0$ \\
Articulated vehicle & $0,5-0,9$ \\
\hline Sumber Data : M. Ehsani $(2005)^{5)}$
\end{tabular}

\section{- $\quad$ Beban Tanjakan $\left(F_{s t}\right)$}

Beban tanjakan merupakan gaya gravitasi yang bekerja dengan kemiringan tertentu sebesar $\theta$ dengan arah berlawanan terhadap gerakan kendaraan naik atau turun dari kendaraan. Berikut adalah ilustrasi dari beban tanjakan yang terjadi pada kendaraan yang melaju pada jalan dengan kemiringan tertentu. Beban tanjakan ditunjukkan oleh gaya dengan besaran $\mathrm{W}$ Sin $(\theta)$ dimana $\theta$ merupakan besarnya sudut tanjakan yang dialami oleh kendaraan.

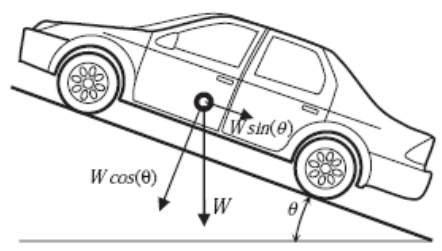

Gambar 6.

Beban Tanjakan

Dari ilustrasi di atas diperoleh bahwa perhitungan beban tanjakan dengan kemiringan terhadap bidang horizontal sebesar $\theta$ adalah:

$$
F_{\mathrm{st}}= \pm(m * g * \sin \theta)
$$

Keterangan:

$$
\begin{array}{ll}
F_{S t} & : \text { Beban tanjakan }(\mathrm{N}) \\
m & : \text { Massa kendaraan }(\mathrm{kg}) \\
g & : \text { Konstanta gravitasi }\left(\mathrm{m} / \mathrm{s}^{2}\right) \\
\theta & : \text { Sudut tanjakan }\left({ }^{\circ}\right)
\end{array}
$$

Tanda postif atau negatif dari beban tanjakan hanya merupakan penanda apakah gaya bekerja pada kondisi tanjakan atau turunan.

\section{- $\quad$ Total Beban Kendaraan $\left(F_{R o+} F_{L+} F_{S t}\right)$}

Total beban yang dialami kendaraan merupakan resultan dari ketiga gaya yaitu beban rolling, beban aerodinamis dan beban tanjakan ${ }^{4,6)}$. Perhatikan Gambar 5., total beban kendaraan merupakan penjumlahan dari $F_{R o}, F_{L}$ dan $F_{S t}$.

\section{Perhitungan Traksi Roda pada Kendaraan Taktis WCV}

Setiap kendaraan beroda harus mengelola perpindahan daya dari mesin ke bodi kendaraan. Untuk mencapai ini, perangkat yang digunakan yaitu mulai dari mesin di seluruh kopling, gearbox, dan juga roda. Untuk mencapai kecepatan kendaraan maksimum yang tinggi, dengan kombinasi akselerasi yang baik pada seluruh rentang kecepatan, maka diperlukan sistem gearing, yang memungkinkan mesin beroperasi pada kecepatan yang sesuai dengan performa terbaiknya).

Untuk memvisualisasikan proses ini dan untuk memperkirakan rasio roda gigi apa yang dibutuhkan, maka plot dari kecepatan kendaraan terhadap traksi dapat digunakan. Untuk menghitung traksi kendaraan terlebih dahulu dilakukan perhitungan kecepatan. Kecepatan kendaraan dapat dihitung berdasarkan rumus berikut ${ }^{4)}$ :

$$
v(\mathrm{~km} / \mathrm{jam})=\frac{\omega \times 2 \times \pi \times r_{W} \times 60}{n_{g} \times n_{f} \times 1000}
$$

dimana:

$$
\begin{array}{ll}
v & : \text { Kecepatan kendaraan }(\mathrm{km} / \mathrm{jam}) \\
\omega & : \text { Kecepatan putaran mesin }(\mathrm{rpm}) \\
r_{w} & : \text { Radius roda }(\mathrm{m}) \\
n_{g} & : \text { Gear ratio } \\
n_{f} & : \text { Wheel axle ratio }
\end{array}
$$

Rumus di atas telah disesuaikan dengan satuan yang diharapkan dimana wheel axle ratio adalah data final gear ratio. Selanjutnya traksi roda di masing-masing gear dapat dihitung berdasarkan rumus berikut4):

$$
T_{W}=\frac{n_{g} \times n_{f} \times T_{e} \times \eta_{d}}{r_{W}}
$$

dimana:

$\begin{array}{ll}T_{w} & : \text { Kecepatan kendaraan }(\mathrm{km} / \mathrm{jam}) \\ r_{w} & : \text { Radius roda }(\mathrm{m}) \\ n_{g} & : \text { Gear ratio } \\ n_{f} & : \text { Wheel axle ratio } \\ T_{E} & : \text { Torsi engine }(\mathrm{N} . \mathrm{m}) \\ \eta_{d} & : \text { Efisiensi powertrain }\end{array}$

\section{HASIL DAN PEMBAHASAN}

Simulasi performa WCV dengan rolling chassis merek A, merek B dan merek C dilakukan dengan asumsi sebagai berikut:

- Berat kendaraan dalam keadaan kapasitas maksimum (GVW) kendaraan tersebut 
- Efisiensi powertrain adalah $80 \%$. Nilai ini diambil berdasarkan hasil studi Piechottka, et al, 20188).

- Kontak roda - jalan tidak mengalami slip

\section{Simulasi Performa WCV dengan Rollling Chassis Merek A}

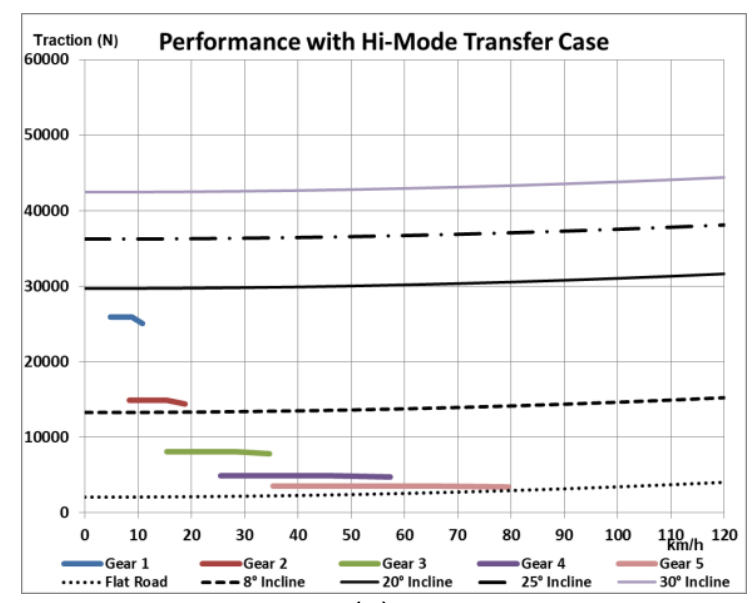

(a)

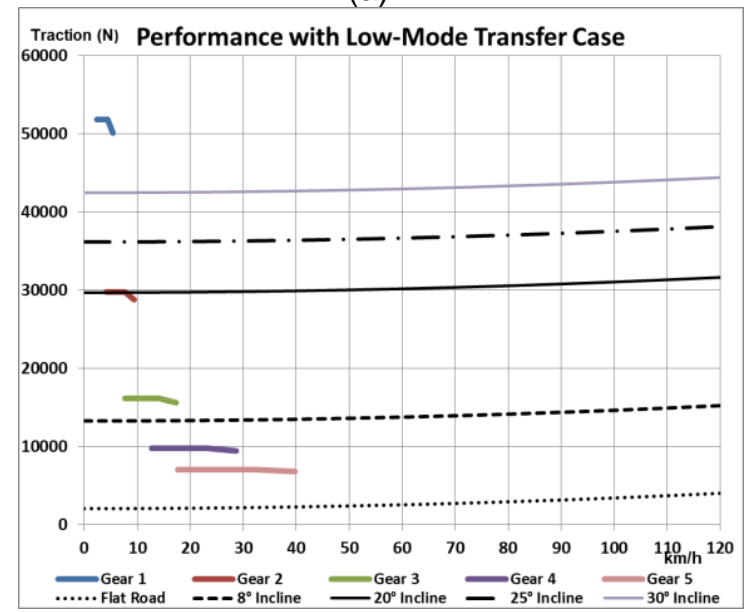

(b)

Gambar 7.

Performa WCV dengan rolling chassis merek $A$

Performa rolling chassis merek A dilakukan dengan menganalisa performa engine yang diperoleh dari data atau kurva torsi engine 4HG1-T. Namun data engine 4HG1-T ini tidak diperoleh dalam bentuk kurva torsi. Oleh karena itu, analisa dilakukan dalam bentuk perhitungan dari spesifikasi torsi maksimum dan daya maksimum yang dihasilkan mesin dari spesifikasi rolling chassis. Diketahui bahwa torsi maksimum untuk engine 4HG1-T yaitu $343 \mathrm{Nm}$ pada putaran 1200-2200 RPM (lihat Tabel 2). Pada rentang ini kemudian dihitung kecepatan kendaraan menggunakan formula (4). Gambar berikut menunjukkan performa WCV dengan rolling chassis merek A pada penggunaan transfer case dengan posisi himode dan low-mode.

Peforma WCV dapat diinterpretasikan dari grafik dimana jika traksi yang dihasilkan di masing-masing gear berada di atas total beban yang dialami kendaraan pada tanjakan/ inklinasi tertentu artinya tanjakan tersebut dapat dilewati dengan penggunaan gear yang dimaksud. Pada hi-mode, performa WCV dengan rolling chassis merek A dari gambar 7(a) menunjukkan kemampuan untuk mendaki pada tanjakan lebih dari $8^{\circ}$ dengan gear 1 atau 2 dengan kecepatan hingga 18,8 $\mathrm{km} / \mathrm{jam}$ jika menggunakan gear 2. Namun WCV desain ini tidak mampu menanjak pada kemiringan lebih dari $20^{\circ}$, ditunjukkan dengan nilai traksi yang kurang dari beban jalan kendaraan pada tanjakan lebih dari $20^{\circ}$. Pada penggunaan di jalan datar, kendaraan WCV desain memiliki kecepatan maksimum sebesar $79,5 \mathrm{~km} / \mathrm{jam}$. Dari pengoperasian dengan hi-mode menghasilkan traksi maksimum 25,05 kN.

Pada low-mode (gambar 7(b)) diketahui kemampuan untuk mendaki dapat mencapai tanjakan lebih dari $30^{\circ}$ dengan kecepatan hingga $5,4 \mathrm{~km} / \mathrm{jam}$ (gear 1). Traksi maksimum yang dihasilkan dari pengoperasian ini adalah 50,09 kN. Pada penggunaan di jalan datar, kendaraan WCV desain dengan setting ini memiliki kecepatan maksimum sebesar 39,7 km/jam. Pengoperasian low-mode ini memungkinkan kendaraan untuk dioperasikan dengan gear 2 untuk melalui tanjakan dengan kemiringan lebih dari $20^{\circ}$ dengan kecepatan maksimum sebesar $8 \mathrm{~km} / \mathrm{jam}$ dan gear 3 untuk tanjakan $8^{\circ}$ dengan kecepatan maksimum sebesar $17,3 \mathrm{~km} / \mathrm{jam}$.

\section{Simulasi Performa WCV dengan Rollling} Chassis Merek B

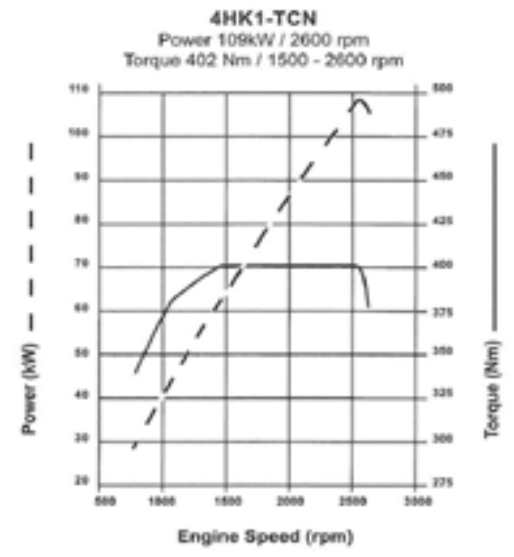

Gambar 8.

Kurva Performa Engine 4HK1-TCN 
Simulasi Beban Jalan Dan Traksi Roda Pada Pemilihan Rolling Chassis 4WD untuk Kendaraan Water Cannon (Prasetyaning Diah Rizky Lestari, Agus Sartomo \& Taufik Yuwono)

Spesifikasi performa engine 4HK1-TCN yang digunakan pada rolling chassis merek $\mathrm{B}$ ditunjukkan dalam gambar berikut.

Hasil simulasi performa rolling chassis merek $B$ berdasarkan kurva performa engine di atas adalah sebagai berikut.

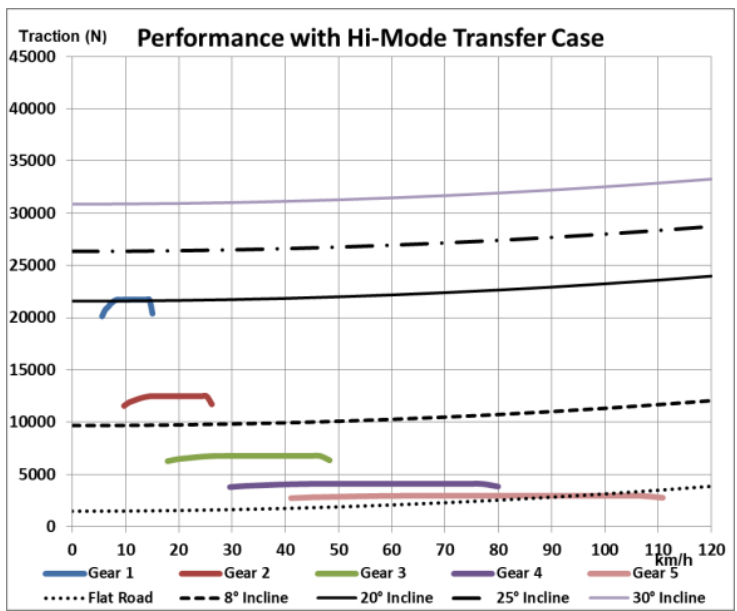

(a)

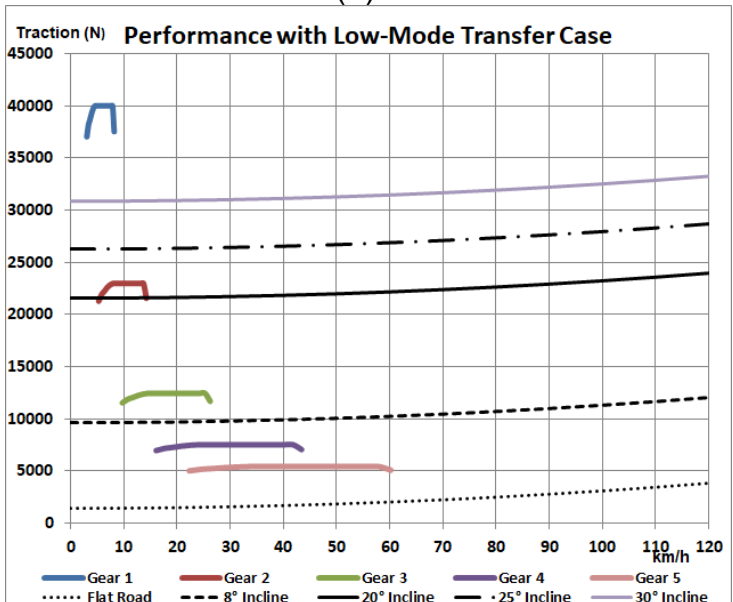

(b)

Gambar 9.

Performa WCV dengan rolling chassis merek B

Pada hi-mode, performa WCV dengan rolling chassis merek B di atas menunjukkan kemampuan untuk mendaki pada tanjakan $20^{\circ}$ dengan kecepatan antara 8,4 hingga 14,5 $\mathrm{km} / \mathrm{jam}$. Hal ini ditunjukkan dengan nilai traksi kendaraan yang sedikit melebihi beban jalan kendaraan pada tanjakan $20^{\circ}$. Pada penggunaan di jalan datar, kendaraan WCV desain memiliki kecepatan maksimum sebesar $95 \mathrm{~km} / \mathrm{jam}$. Grafik di atas juga menunjukkan bahwa WCV desain dapat digunakan untuk melalui tanjakan $8^{\circ}$ dengan kecepatan maksimum 26,2 km/jam pada pengoperasian gear 2. Traksi maksimum yang dihasilkan pada pengoperasian ini adalah sebesar $21,73 \mathrm{kN}$.
Sedangkan pada penggunaan dengan low-mode menunjukkan kemampuannya untuk digunakan pada tanjakan dengan lebih dari $30^{\circ}$ dengan kecepatan hingga 8,2 $\mathrm{km} / \mathrm{jam}$ menggunakan gear 1. Hal ini ditunjukkan dengan nilai traksi yang lebih tinggi dari beban jalan kendaraan pada tanjakan $30^{\circ}$. Penggunaan low-mode pada WCV desain menghasilkan kecepatan maksimum sebesar 60,2 km/jam (gear 5). Grafik di atas menunjukkan penggunaan WCV desain dengan gear 2 pada low-mode dapat digunakan pada tanjakan $20^{\circ}$ dengan kecepatan maksimum 14,2 $\mathrm{km} / \mathrm{jam}$. Pengoperasian dengan gear 3 dapat digunakan untuk tanjakan $8^{\circ}$ dengan kecepatan maksimum sebesar 26,2 km/jam. Traksi maksimum yang dihasilkan pada pengoperasian ini adalah sebesar 40,01 kN.

\section{Simulasi Performa WCV dengan Rollling Chassis Merek C}

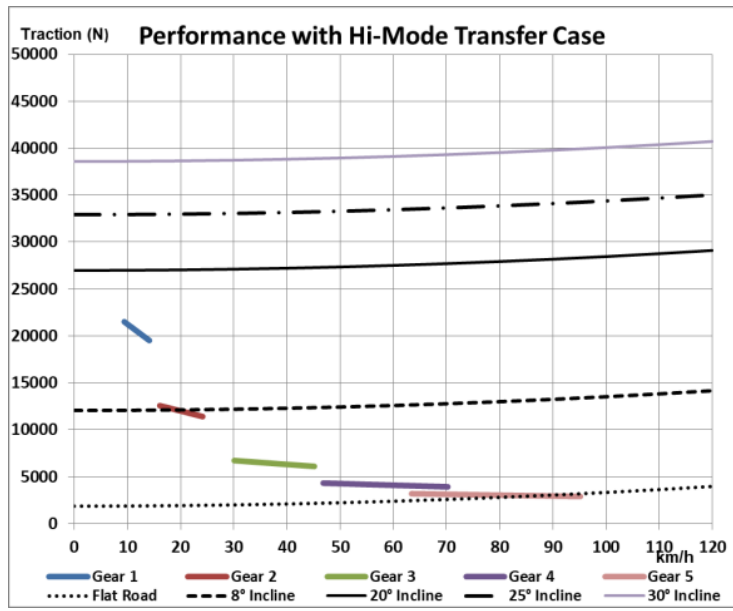

(a)

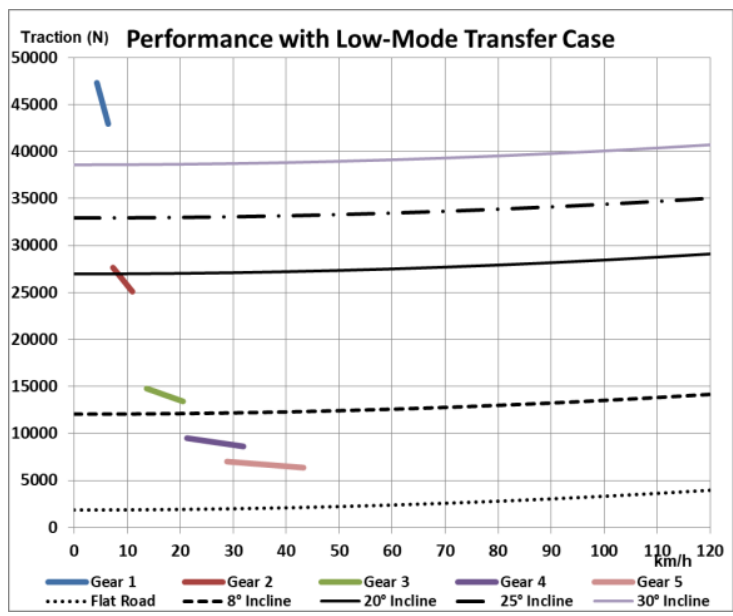

(b)

Gambar 10.

Performa WCV dengan rolling chassis merek C 
Sama halnya dengan engine 4HG1-T untuk merek $\mathrm{A}$, rolling chassis merek $\mathrm{C}$ menggunakan engine W04D-TR yang data kurva torsinya tidak tersedia. Sehingga analisa performa engine dilakukan dalam bentuk perhitungan dari spesifikasi torsi maksimum dan daya maksimum yang dihasilkan mesin dari spesifikasi rolling chassis. Gambar berikut menunjukkan performa WCV dengan rolling chassis merek $C$ pada penggunaan transfer case dengan posisi hi-mode dan low-mode.

Grafik traksi dan beban jalan WCV dengan rolling chassis merek C pada penggunaan transfer case dengan hi-mode menunjukkan kemampuan untuk mendaki pada tanjakan lebih dari $8^{\circ}$ dengan kecepatan sekitar $14,1 \mathrm{~km} / \mathrm{jam}$ dengan gear 1. Hal ini ditunjukkan dengan nilai traksi kendaraan melebihi beban jalan kendaraan pada tanjakan $8^{\circ}$. Pada penggunaan di jalan datar, kendaraan WCV desain memiliki kecepatan maksimum sebesar $90 \mathrm{~km} / \mathrm{jam}$. Grafik di atas juga menunjukkan bahwa WCV desain dapat digunakan untuk melalui tanjakan $8^{\circ}$ dengan kecepatan maksimum sekitar $19 \mathrm{~km} / \mathrm{jam}$ pada pengoperasian gear 2. Traksi maksimum yang dihasilkan pada pengoperasian ini adalah sebesar $21,51 \mathrm{kN}$.
Sedangkan pada penggunaan dengan low-mode menunjukkan kemampuannya untuk digunakan pada tanjakan dengan lebih dari $30^{\circ}$ dengan kecepatan hingga 6,4 $\mathrm{km} / \mathrm{jam}$ dengan gear 1. Hal ini ditunjukkan dengan nilai traksi yang lebih tinggi dari beban jalan kendaraan pada tanjakan $30^{\circ}$. Penggunaan low-mode pada WCV desain menghasilkan kecepatan maksimum sebesar $43,3 \mathrm{~km} / \mathrm{jam}$. Grafik di atas menunjukkan penggunaan WCV desain dengan gear 2 pada low-mode dapat digunakan pada tanjakan $20^{\circ}$ dengan kecepatan maksimum sekitar $8 \mathrm{~km} / \mathrm{jam}$. Pengoperasian dengan gear 3 dapat digunakan untuk tanjakan $8^{\circ}$ dengan kecepatan maksimum sebesar 20,5 $\mathrm{km} / \mathrm{jam}$. Traksi maksimum yang dihasilkan pada pengoperasian ini adalah sebesar 47,31 $\mathrm{kN}$.

\section{Perbandingan Performa 3 Kandidat Rolling Chassis}

Dari hasil simulasi diatas dapat diperoleh perbandingan tiga jenis rolling chassis merek $A$, merek $B$ dan merek $C$ sebagai berikut.

Tabel 5.

Tinjauan Utama Perbandingan 3 Rolling Chassis

\begin{tabular}{|c|c|c|c|c|c|c|}
\hline \multirow{3}{*}{ Aspek Tinjauan } & \multicolumn{6}{|c|}{ Rolling Chassis } \\
\hline & \multicolumn{2}{|c|}{ Merek A } & \multicolumn{2}{|c|}{ Merek B } & \multicolumn{2}{|c|}{ Merek C } \\
\hline & $\begin{array}{l}\text { Hi- } \\
\text { mode }\end{array}$ & $\begin{array}{l}\text { Low- } \\
\text { Mode }\end{array}$ & $\begin{array}{c}\text { Hi- } \\
\text { mode }\end{array}$ & $\begin{array}{l}\text { Low- } \\
\text { Mode }\end{array}$ & $\begin{array}{l}\text { Hi- } \\
\text { mode }\end{array}$ & $\begin{array}{l}\text { Low- } \\
\text { Mode }\end{array}$ \\
\hline Tanjakan $30^{\circ}$ & $x$ & $\sqrt{ }$ & $\times$ & $\sqrt{ }$ & $x$ & $\sqrt{ }$ \\
\hline Tanjakan $25^{\circ}$ & $x$ & $\sqrt{ }$ & $x$ & $\sqrt{ }$ & $x$ & $\sqrt{ }$ \\
\hline Tanjakan $20^{\circ}$ & $x$ & $\sqrt{ }$ & $\sqrt{ }$ & $\sqrt{ }$ & $x$ & $\sqrt{ }$ \\
\hline $\begin{array}{l}\text { Kecepatan maksimum pada tanjakan } \\
30^{\circ}(\mathrm{km} / \mathrm{jam})\end{array}$ & & 5,4 & & 8,2 & & 6,4 \\
\hline $\begin{array}{l}\text { Kecepatan maksimum pada tanjakan } \\
25^{\circ}(\mathrm{km} / \mathrm{jam})\end{array}$ & & 5,4 & & 8,2 & & 6,4 \\
\hline $\begin{array}{l}\text { Kecepatan maksimum pada tanjakan } \\
20^{\circ}(\mathrm{km} / \mathrm{jam})\end{array}$ & & 8 & 14,5 & 14,2 & & 8 \\
\hline $\begin{array}{l}\text { Kecepatan maksimum pada tanjakan } 8^{\circ} \\
\text { (km/jam) }\end{array}$ & 18,8 & 17,3 & 26 & 26,2 & 19 & 20,5 \\
\hline Kecepatan maksimum (km/jam) & 79,5 & 39,7 & 95 & 60,2 & 90 & 43,3 \\
\hline Traksi maksimum $\left(\times 10^{3} \mathrm{kN}\right)$ & 25,05 & 50,09 & 21,73 & 40,01 & 21,51 & 47,31 \\
\hline
\end{tabular}

Dari tabel di atas dapat dilihat bahwa merek B mampu hingga tanjakan $30^{\circ}$ dengan kecepatan paling tinggi yaitu $8,2 \mathrm{~km} / \mathrm{jam}$. Untuk pengoperasian hi-mode, hanya merek $B$ yang mampu menanjak hingga $20^{\circ}$ dengan kecepatan hingga $14,5 \mathrm{~km} / \mathrm{jam}$. Secara keseluruhan untuk setiap tanjakan, merek B menunjukkan kecepatan paling unggul.
Dalam hal kecepatan maksimum, merek $B$ juga paling mampu hingga $60,2 \mathrm{~km} / \mathrm{jam}$ saat low-mode. Traksi yang dihasilkan merek B dan $C$ tidak jauh berbeda. Selain itu, jarak wheel base (lihat Tabel 2.) juga merupakan pertimbangan lainnya. Diketahui bahwa jarak wheel base merek $B$ lebih pendek dari merek $\mathrm{C}$, maka rolling chasis merek $\mathrm{B}$ juga lebih layak digunakan, karena dengan jarak wheel base yang lebih pendek, kendaraan WCV akan lebih mudah untuk bermanuver. 


\section{SIMPULAN DAN SARAN}

Dari data-data di atas yaitu dengan telah dilakukannya simulasi performa rolling chassis dengan 3 merek A, B dan C maka dapat disimpulkan bahwa secara keseluruhan desain kendaraan WCV dengan menggunakan rolling chassis merek $\mathrm{B}$ lebih unggul untuk digunakan jika dibandingkan dengan merek A dan C. Dengan rolling chassis merek B, kendaraan WCV dapat melalui tanjakan hingga $30^{\circ}$ dengan kecepatan paling tinggi yaitu $8,2 \mathrm{~km} / \mathrm{jam}$ pada pengoperasian dengan low-mode. Simulasi beban jalan kendaraan dan traksi roda ini dapat digunakan sebagai salah satu metode acuan pemilihan rolling chassis untuk kendaraan WCV. Hasil simulasi yang ditampilkan akan lebih akurat jika data kurva torsi untuk setiap engine yang digunakan pada masing-masing rolling chassis juga tersedia. Dalam hal ini, perhitungan simulasi performa untuk merek $\mathrm{A}$ dan $\mathrm{C}$ belum mendekati nilai aslinya karena tidak adanya data berupa kurva torsi.

\section{DAFTAR PUSTAKA}

1. PTIPK-BPPT, Laporan Akhir Kegiatan Inovasi dan Layanan Teknologi Kendaraan Tempur, Kendaraan Taktis dan Munisi Kaliber Besar, BPP Teknologi, Indonesia, Desember 2015.

2. Sartomo, A., dan Lestari, P.D.R., Kajian Pemilihan Rolling Chasis Untuk Kendaraan Taktis Water Cannon Berdasarkan Analisa Distribusi Beban Kendaraan, Jurnal Teknik Mesin Untirta, Vol. III No. 2, Flywheel, Indonesia, 2017.
3. Cesar, W., dan Hasrito, E.S., Perancangan Model Sistem Kendali Kendaraan Water Cannon Berbasis Microcontroller Raspberry PI, Jurnal Teknik Elektro Untar, Vol. 18 No. 1, TESLA, Indonesia, 2016.

4. Mashadi, B., and Crolla, D., Vehicle Powertrain Systems, John Wiley \& Sons, Ltd., UK, 2012.

5. Ehsani, M., Modern Electric, Hybrid Electric and Fuel Cell Vehicles: Fundamentals, Theory and Design, CRC Press, 2005.

6. Gillespie, T.D., Fundamentals of Vehicle Dinamics, Society of Automotive Engineers, Inc., USA, 1992.

7. Repčić, N., Šarić, I., and Avdić, V., Tractive Effort Curves in Gearbox Analyse, 15th International Research/Expert Conference "Trends in the Development of Machinery and Associated Technology", 2011.

8. Piechottka, H., Kucukay, F., Kercher, F., and Bargende, M., Optimal Powertrain Design through a Virtual Development Process, World Electric Vehicle Journal 2018, 9, 11; DOI:10.3390/wevj9010011.

9. Sahraeian, A., Shahbakhti, M., Aslani, A. R., Jazayeri, S.A., Azadi, S., and Shamekhi, A. H., Longitudinal Vehicle Dynamics Modeling on the Basis of Engine Modeling, DOI: 10.4271/200401-1620, 2004.

10. Hirz, M, Basics of longitudinal vehicle dynamics, Graz University of Technology, 2015.

11. Rill, G., Vehicle Dynamics, Ostbayerische Technische Hochschule (OTH) Regensburg, 2007.

12. Wallentowitz, H., Longitudinal Dynamics of Vehicles, Vervielfältigungsstelle der Hochschule, 2004. 
(halaman ini sengaja dikosongkan) 